\title{
Enhance nitrogen removal in bioretention cells with addition of hydrothermal pre-treated pine barks as external carbon source
}

Jing Tuo ( $\nabla$ tjyx914@163.com )

Nanjing Forestry University https://orcid.org/0000-0003-2338-381X

Shiwei Cao

Nanjing Forestry University

Muzi Li

Nanjing Forestry University

Rong Guo

Nanjing Forestry University

\section{Research Article}

Keywords: Pine barks, External carbon source, Hydrothermal pretreatment, Nitrogen removal, COD removal, Bioretention cells

Posted Date: September 29th, 2021

DOl: https://doi.org/10.21203/rs.3.rs-840647/v1

License: (9) This work is licensed under a Creative Commons Attribution 4.0 International License. Read Full License 


\section{Abstract}

The problem of poor carbon source is a common factor limiting the nutrients removal in bioretention cells (BRCs). This study aimed to investigate the feasibility of using modified biomass in BRCs filled with a mixture of fly ash ceramsite and pumice fillers to enhance nitrogen removal. Different pretreatment methods (hydrothermal-treated, acid-treated and alkali-treated) were attempted, and hydrothermal pretreatment showed a best performance in carbon release ability. The scanning electron microscopy showed that the lignin in hydrothermal pretreated pine barks (H-PBs) was destroyed, and the fiber structure became thinner with more irregular folds, which improved the accessibility of cellulose and attachment of microorganisms. The addition of $\mathrm{H}-\mathrm{PBs}$ significantly enhanced the nutrients removal in BRCs, and the removal rates of $\mathrm{TN}$ and $\mathrm{NO}_{3}{ }^{-}-\mathrm{N}$ increased by $23.25 \%$ and $38.22 \%$ compared with those in BRC-A (without external carbon source), but the removal rate of $\mathrm{NH}_{4}{ }^{+}-\mathrm{N}$ was inferior to BRC-A. Besides, the large carbon release amount of H-PBs did not deteriorate the effluent quality, with COD removal rate of $87.98 \%$ in the $48 \mathrm{~d}$. These results indicate that the BRCs by adding H-PBs could intensify the denitrification process.

\section{Introduction}

The nitrogen removal performance of bioretention basins is variable, especially for $\mathrm{NO}_{3}{ }^{-}-\mathrm{N}$, owing to the lack of carbon source and anaerobic conditions (Zhang et al., 2021). The application of natural materials (sawdust, wood bark, straw, calamus and other agricultural waste products) for an additional carbon source to solve the carbon shortage in bioretention cells (BRCs) for rainwater with a low $\mathrm{C} / \mathrm{N}$ (COD/nitrogen ratio) is well-known (Wang et al., 2021). One of the promising biomass carbon source is pine bark (PB) representing wastes of timber harvesting and timber processing. It's because of the largeyield and easy availability of PB that its comprehensive utilization has received much attention. It can be used in many areas, for example, it is now widely used in landscaping, environmental protection, agricultural planting and other fields. Also, it can be used as biological filter material because of its high porosity, which has good adsorption, water retention and microbial carrying benefits in biological treatment systems. At the same time, PB has stable physical and chemical characteristics, containing large quantities of $\mathrm{N}, \mathrm{P}, \mathrm{K}, \mathrm{Ca}, \mathrm{Mg}$ and other elements (Augoustides et al., 2021). In addition, PB, as a lignocellulosic material, can be decomposed into glucose and oligosaccharides by microorganisms, and its high organic matter content makes it a novel denitrifying carbon source. Biomass carbon source such as PBs are cheaper and environmentally friendly compared with traditional carbon source (Luo et al., 2018). Due to secondary pollution, lignin encapsulation and instability of release (Hu et al., 2019), many researches have explored the influence of carbon source modification or pretreatment on denitrification performance. Different pretreatment methods lead to different degrees of damage to plant structure, as well as different carbon release patterns and total amounts. Pretreatment of lignocellulosic biomass is a prerequisite step for biological conversion because of the structural complexity of cellulose, hemicellulose and lignin, limited degradability of lignin and formation of inhibitory products during microbial fermentation. Therefore, the selection of appropriate pretreatment methods is of great 
significance to improve the availability of biomass carbon source. The most common ones are the shearing, grinding, ultrasonic treatment, acid treatment, alkali treatment and hydrothermal treatment of the carbon source. In liquid hot water pretreatment, water in the liquid phase at high temperature and pressure was used to breakdown the celluloses and hemicelluloses structure that was bound by lignin. For most BRCs, the carbon source cannot be guaranteed, so many researchers have added biomass such as agricultural wastes for BRCs and achieved good nitrogen removal. Zhu et al. (2021) found that denitrifications and organic-degrading bacterial were enriched after the addition of rotten fruits as external carbon source. Zhong et al. (2019) explored the feasibility of using microalgae biomass to enhance the denitrification rate and found that nitrate removal and total nitrogen removal were improved by $27.9 \%$ and $17.7 \%$, respectively. Saliling et al. (2007) evaluated wood chips and wheat straw as substrates for denitrification process and it showed that both wood chips and wheat straw produced comparable denitrification rate. However, research on PBs as the BRCs carbon source is limited, lacking the effects of carbon release and nitrogen removal of PBs, especially for the pre-treated PBs. PB, as a kind of agricultural waste, has a large yield. If it can be pretreated effectively, it will be an effective and cheap denitrification carbon source.

Traditional BRCs usually use a mixture of local soil, quartz sand, and other pretreated materials as substrates (Luo et al., 2020b). In order to improve the combination of fillers in BRCs, Fly ash ceramsite (FC) and Pumice (PC) were chosen as substrates in this experiment. FC has the advantages of large specific surface area, high porosity, good impact load resistance, and stable chemical properties (Qin et al., 2015). Moreover, it is a cheap adsorbent as it has strong adsorption in the presence of active sites such as aluminum and silicon oxides and is easy to regenerate (Cheng et al., 2018). PC is a kind of good microbial carrier material because of its high porosity, and it is also widely used in water treatment (Rashad et al., 2019).

In this study, PBs were selected as an external carbon source through experiments, and hydrothermal pretreated pine barks (H-PBs) were prepared to solve the carbon shortage in BRCs. The main objectives of this study are to (a) compare pretreatment conditions and analyze pretreatment mechanism of PBs;(b) study the feasibility of utilizing H-PBs as external carbon source to enhance denitrification process in BRCs. Therefore, this study will be helpful for the practical application of PBs in nitrogen removal intensification of BRCs.

\section{Materials And Methods}

\subsection{Agricultural material}

The PBs were collected in the field of Jiangsu Province, China. They were washed with ultrapure water, air-dried at room temperature and cut into $2 \mathrm{~cm}$ pieces. Then, the PBs were dried in the oven at $105^{\circ} \mathrm{C}$ (GZX-9140MBE, Shanghai, China) to a constant weight. Finally, the prepared PBs were stored in a dryer until used.

\subsection{Experimental design}




\subsubsection{Optimization of pretreatment conditions}

Different pretreatment conditions of PBs carbon source were compared in the leaching experiments. Firstly, $10 \mathrm{~g}$ PBs were added to the $250 \mathrm{~mL}$ Erlenmeyer flasks with $100 \mathrm{ml}$ ultrapure water, $100 \mathrm{~mL}$ $1 \% \mathrm{H}_{2} \mathrm{SO}_{4}$ and $100 \mathrm{~mL} 2 \square \mathrm{NaOH}$, respectively. The carbon sources for study were untreated, hydrothermaltreated, acid-treated and alkali-treated PBs. To obtain H-PBs, PBs were treated in an autoclave at $140{ }^{\circ} \mathrm{C}$ for $1 \mathrm{~h}$. To obtain acid-treated and alkali-treated PBs, PBs were treated in $100 \mathrm{~mL} 1 \mathrm{HH}_{2} \mathrm{SO}_{4}$ and $100 \mathrm{~mL}$ $2 \varangle \mathrm{NaOH}$ respectively at $25^{\circ} \mathrm{C}$ for $1 \mathrm{~h}$. Then, $2.5 \mathrm{~g}$ different pre-treated PBs after washing with ultrapure water and air-dried were added to $250 \mathrm{~mL}$ Erlenmeyer flasks with $200 \mathrm{~mL}$ ultrapure water respectively. Finally, leachate of pretreated PBs in the flasks were detected at 24, 48, 96, 150, 240, 264, 360, $720 \mathrm{~h}$, soluble and insoluble COD contents in the leachate were measured.

\subsubsection{Characteristic analysis}

PBs and H-PBs were subjected to the leaching experiment (Tao et al., 2021) according to the methods in the previous section. The lignocellulose composition of PBs before and after pretreatment was analyzed by Van Soest (Van Soest et al., 1991). The surface morphology of PB samples were assessed by scanning electron microscopy (SEM, Ultra 55, Zeiss, Oberkochen, Germany). Each dried sample before and after pretreatment were sliced, fixed and gold-sputtered before observation. Moreover, for kinetic study, $2.5 \mathrm{~g} \mathrm{H}$-PBs were added to $250 \mathrm{~mL}$ Erlenmeyer flasks with $200 \mathrm{~mL}$ ultrapure water. Then, leachate in the flasks was taken on 24, 48, 96, 150, 240, 264, 360, $720 \mathrm{~h}$. Finally, soluble COD contents in the leachate were measured and Ritger-Peppas equation (Ritger and Peppas., 1987) was employed to simulate the release behavior of H-PBs as follows:

$$
\frac{M \mathrm{t}}{M_{\infty}}=a^{*} t^{n}
$$

Where $t$ is carbon release time; $a$ is release rate constant; $n$ is release exponent; $M_{t}$ and $M_{\infty}$ show amounts of soluble COD at time $t$ and after infinite time, respectively.

\subsection{Design and operation of experimental BRCs}

Three lab-scale BRCs (BRC-A, BRC-B, BRC-C) were established in the laboratory at Nanjing Forestry University in Nanjing, China (Fig. 1). Each system was composed of a $9 \mathrm{~cm}$-pumice layer and a $30 \mathrm{~cm}$ ceramsite layer. Specific information of fillers was shown in Table 1. There was a $6 \mathrm{~cm}$-H-PBs covering for BRC-C, a $6 \mathrm{~cm}$-untreated PBs covering for BRC-B and no covering for BRC-A. The diameter and height of each device was: $0.1 \mathrm{~m} \times 0.7 \mathrm{~m}$, planted with Cyperus alternifolius $L$. The detailed information of simulated rainwater could be found in Table 2 . The rainfall intensity with rainfall return period of 5 years and rainfall duration of 120 min was calculated, and the total catchment aera and integrated runoff coefficient were used to calculate influent area. The experiment used submersible pumps to enter the simulated rainwater, and the hydraulic retention time of each device was $1 \mathrm{~d}$.

\subsection{Water Quality Analysis}


The effluents and influent were taken after $1 \mathrm{~d}$. The water quality of each device were analyzed, including $\mathrm{TN}, \mathrm{NO}_{3}{ }^{-}-\mathrm{N}, \mathrm{NH}_{4}{ }^{+}-\mathrm{N}$ and $\mathrm{COD}$, according to the standard methods (APHA, 2012). $\mathrm{NH}_{4}{ }^{+}-\mathrm{N}_{1} \mathrm{NO}_{3}{ }^{-}-\mathrm{N}$ and TN were detected by a UV spectrophotometer (Shimadzu UV-2600, Japan), and the determination of COD was performed using the Potassium dichromate rapid method. Furthermore, $\mathrm{TN}, \mathrm{NO}_{3}{ }^{-} \mathrm{N}, \mathrm{NH}_{4}{ }^{+}-\mathrm{N}$ and $\mathrm{COD}$ removal rate $(R, \%)$ were calculated by using Eq. (2):

$$
R=\frac{C_{\mathrm{i}}-C_{0}}{C_{\mathrm{i}}} \times 100 \%
$$

Where $C_{i}$ and $C_{O}$ are the $\mathrm{TN} / \mathrm{NO}_{3}{ }^{-} \mathrm{N} / \mathrm{NH}_{4}{ }^{+}-\mathrm{N} / \mathrm{COD}$ concentration of the influent and effluent, respectively.

\section{Results And Discussion}

\subsection{Comparison of pretreatment conditions}

In this study, four kinds of pretreated PBs (untreated, hydrothermal-treated, acid-treated and alkali-treated) were compared and their release of COD were analyzed. The specific experimental results were shown in Fig. 2. The COD release amount of H-PBs was significantly greater than that of the others, with the total COD reaching to $213.24 \mathrm{mg} / \mathrm{g}$ and the soluble COD reaching to $188.16 \mathrm{mg} / \mathrm{g}$ within $24 \mathrm{~h}$. While the COD release amount of acid-treated PBs was lower than that of untreated PBs, and the COD release of acidtreated PBs was only half of that of untreated PBs at the end of the experiment. After $5 \mathrm{~d}$, the COD release rate of PBs was accelerated. The total COD release of hydrothermal treatment was the highest with concentration of total COD and soluble COD as high as $716.27 \mathrm{mg} / \mathrm{g}$ and $505.25 \mathrm{mg} / \mathrm{g}$ on the 30th day, while the total COD release of alkali treatment, untreated treatment and acid treatment was $490.68 \mathrm{mg} / \mathrm{g}$, $457.64 \mathrm{mg} / \mathrm{g}$ and $272.13 \mathrm{mg} / \mathrm{g}$, and the soluble COD was $378.96 \mathrm{mg} / \mathrm{g}, 335.48 \mathrm{mg} / \mathrm{g}$ and $192.81 \mathrm{mg} / \mathrm{g}$, respectively. After hydrothermal treatment, the soluble COD released from PBs accounted for about $70 \%$ of the total COD release, which is an effective carbon source that can be utilized in the initial rainwater runoff denitrification. Many researches found the hydrothermal treatment can destroy the structure of lignocellulosic biomass and dissolve the hemicelluloses contents, thus exposing the cellulose surface and increasing enzyme accessibility to the cellulose microfibrils (Jeong et al., 2020). Alkali treatment were found to cause swelling, resulting in a decrease in the degree of polymerization (Li et al., 2021) and an increase in internal surface area, which is beneficial to the continuous carbon release of PBs. While Selig et al. (2007) found droplets composing of lignins and possible lignin-carbohydrate complexes were formed on the surface of residual corn stover following acid pretreatment, and these droplets were shown to have a negative effect on the enzymatic saccharification of the substrate, which can account for the low COD release of acid treatment.

It showed that hydrothermal pretreatment could significantly improve the carbon release of PBs comparing the proper 4 pretreatment methods. Also, hydrothermal treatment is an ideal pretreatment method for biomass carbon sources which is more environmental friendly than alkali and acid treatment. 


\subsection{Characteristics of PBs}

\subsubsection{Effect of hydrothermal pretreatment on fiber composition}

Table 2 showed the changes in cellulose composition of PBs before and after hydrothermal pretreatment in this study. It could be seen that hydrothermal treatment increased the content of cellulose in PBs, and decreased the content of hemicellulose, hot water soluble matter, ash and lignin. The results were consistent with other studies, as Xia et al. (2020) found the hemicellulose and some lignin fractions were solubilized as the hydrolysate after liquid hot water pretreatment. Hydrothermal pretreatment can greatly denature the lignocellulosic structure and enhance the fermentable sugar recovery. Furthermore, they also soften the lignin, which acts as a binder during biomass densification (Sarker et al., 2021). Thus the hemicellulose and lignin of PBs will decrease to a certain extent after hydrothermal pretreatment, and the increase of cellulose can provide enough carbon source for denitrification process and improve the nitrogen removal rate.

\subsubsection{Effect of hydrothermal pretreatment on microstructure of PB}

The surface slices and cross-section slices at $\times 100$ magnification of SEM analysis before and after pretreatment are shown in Fig. 3. Untreated PBs have natural mulch on the surface, usually covered with more non-fibrous impurities such as waxy layer, ash, parenchyma cells and adhesives (Yu et al., 2016). After pretreatment, the covering on the surface of PBs were destroyed which mainly caused by the removal of impurities on the surface of fibrocells. At the same time, the internal fracture occurred, the fiber structure became thinner with more irregular folds. The main reason for the change was that hydrothermal treatment destroyed the wrapping of cellulose and hemicellulose by lignin, decreasing the strength of the fiber structure. Removal and redistribution of lignin led to an increase in pore volume and improved the accessibility of cellulose (Liao et al., 2020). Also, the fiber structure became clearer, and more fiber texture was exposed on the cell surface, which probably led to a higher surface area of the substrate and increased the living and attachment space of microorganisms. Similarly, Lee et al. (2020) showed a higher biodegradability of hydrothermally-pretreated sunflower residues compared to the untreated feedstock.

\subsubsection{Kinetics of carbon release of H-PBs}

As can be seen from Fig. 4, the release of dissolved COD of PBs presented a certain regularity after hydrothermally treatment. The H-PBs showed a sustained COD release time and large release amount. In the initial $24 \mathrm{~h}$, the carbon release amount reached $188.16 \mathrm{mg} / \mathrm{g}$, and the carbon release rate increased at a high level for 30 days, reaching to $505.25 \mathrm{mg} / \mathrm{g}$ at $30 \mathrm{~d}$, which was about three times of the initial release amount. Tao et al. (2021) explored the dynamics of carbon release from corncob and found the release of COD increased rapidly on the first day and then tended to stabilize. Zheng et al. (2021) also 
found the release of COD reached the highest on the first day and finally remained stable. The reason for the higher release of COD at the beginning of the experiment was due to the fast decomposition of small molecular substances attached to the surface of corncob and the release of soluble carbon from the plants (Liu et al., 2018). With the extension of the release time, the inside organics of PBs were further decomposed and released and the COD concentration in the aqueous solution mainly came from the hydrolysis of the cellulose material. The PBs can still release carbon source steadily at $30 \mathrm{~d}$ as hydrothermal treatment opened the PBs fiber structure and improved its biological availability, which can provide sufficient carbon source for denitrification reaction.

The carbon release process of H-PBs fitted the Ritger-Peppas release equation (Fig. 4) best with correlation coefficient $\left(R^{2}\right)$ of 0.97 . Ritger et al. (1987) found that the carbon release was mainly the diffusion process when $\mathrm{n}<0.45$ in the equation, anomalous (non-Fickian) transport when $0.45<\mathrm{n}<0.85$ and case II transport when $n \geq 0.85$. In this carbon release fitting curve, $n=0.34<0.45$ $\left(M_{t} / M_{\infty}=54.14^{\star 0} t^{0.34}\right)$, suggesting the carbon release from H-PBs occurred as a process of Fickian diffusion. Li et al. (2020) found spinosad/chitosan formulation displayed a long sustained-release time $(>18 \mathrm{~d}$ ) and high cumulative release (>80 \%) with release dynamics fitting Fickian diffusion mechanism of Ritger-Peppas model. And Tan et al. (2021) also found materials with controlled release properties (obey the Fick's Laws of diffusion) showed more sustainable and effective activity. The fitted equation indicated H-PBs were suitable as a biomass carbon source for denitrification.

\subsection{Performance of H-PBs as a carbon source in BRCs}

The shortage of carbon is one of the limiting factors for the denitrification in BRCs. In order to solve the problem of unstable removal of $\mathrm{NO}_{3}{ }^{-}-\mathrm{N}$ and $\mathrm{TN}$ in the $\mathrm{BRCs}$, this experiment used PB as an external carbon source to strengthen the nitrogen removal rate of the BRCs. To determine the effect of $\mathrm{H}-\mathrm{PBs}$ and $\mathrm{PBs}$, the investigation on the denitrification performance was conducted with three devices (BRC-A, BRC$\mathrm{B}$, and BRC-C) with different conditions. The variations of $\mathrm{NO}_{3}{ }^{-} \mathrm{N}^{-} \mathrm{NH}_{4}{ }^{+} \mathrm{N}, \mathrm{TN}$ and COD were shown in Fig. 5.

\subsection{1 $\mathrm{NO}_{3}{ }^{-}-\mathrm{N}, \mathrm{NH}_{4}{ }^{+}-\mathrm{N}$ and TN removal rate in BRCs}

Figure 5a showed the impact of $\mathrm{H}-\mathrm{PBs}$ on $\mathrm{NO}_{3}{ }^{-} \mathrm{N}$ removal in $\mathrm{BRCs} . \mathrm{NO}_{3}{ }^{-}-\mathrm{N}$ removal rate gradually increased with the operation of the system. In the initial stage of operation, the concentration of $\mathrm{NO}_{3}{ }^{-} \mathrm{N}$ in effluent was higher than that in influent, and the removal rate was in a negative state $(0-10 \mathrm{~d})$, but the removal rate gradually became higher in the later stage (10-20 d). There were probably several reasons accounting for this: One possible explanation is that the number of denitrifying bacteria in the device was small and the denitrifying was not obvious in the initial stage of operation. Furthermore, the system has not set up a saturated zone at the bottom of device, which cannot provide strict anoxic area for denitrifying bacteria to carry out denitrification. In addition, the removal of $\mathrm{NO}_{3}{ }^{-}-\mathrm{N}$ by microorganisms requires sufficient hydraulic retention time (Kavehei et al., 2021), while the permeability coefficient of FC 
and PC is high, thus the retention time of rainwater in the system is not enough. On the other hand, $\mathrm{NH}_{4}{ }^{+}-$ $\mathrm{N}$ is converted to $\mathrm{NO}_{3}{ }^{-}-\mathrm{N}$ by nitrifying bacteria, resulting in accumulation of $\mathrm{NO}_{3}{ }^{-} \mathrm{N}$ in the system. In addition, the filler itself contains $\mathrm{NO}_{3}{ }^{-}-\mathrm{N}$, which is washed down during the influent process of the BRCs to make the effluent $\mathrm{NO}_{3}{ }^{-}-\mathrm{N}$ concentration even higher than the influent concentration. The $\mathrm{NO}_{3}{ }^{-} \mathrm{N}$ removal rate of the BRC-C with H-PBs was always highest than that of the other two groups, followed by the BRC-B, and the lowest in the BRC-A. The removal rate of $\mathrm{NO}_{3}{ }^{-}-\mathrm{N}$ in the BRC-C was always positive after the 6th day. At the end of the experiment, the removal rate increased from $-20.8 \%$ in the initial stage to $58.22 \%$, while the removal rate of the other two groups was basically negative in the first $35 \mathrm{~d}$. As we all know, a combination of organic carbon source availability, $\mathrm{NO}_{3}{ }^{-}$availability and anaerobic soils, are required for effective denitrification (Gold et al., 2018). PBs after hydrothermal treatment continued to release carbon source and released a large amount. In BRC-C, H-PBs provided sufficient and lasting carbon source for the denitrifying bacteria in the device, so that the denitrification process could proceed normally. On the other hand, after hydrothermal treatment, the specific surface area and the internal pores of PBs increased, enhancing the $\mathrm{NO}_{3}{ }^{-}-\mathrm{N}$ adsorption capacity. Moreover, the addition of PBs contributed to the establishment of microbial community as denitrification is a reaction process dominated by microorganisms, in which functional microorganisms play a vital role (Wang et al., 2021). Meanwhile, the electron transfer process plays an essential role in the denitrification process, and H-PBs, as the lignocellulosic materials, can provide electron donors for denitrification (Wang et al., 2016).

Figure $5 \mathrm{~b}$ showed the impact of $\mathrm{H}-\mathrm{PBs}$ on $\mathrm{NH}_{4}{ }^{+}-\mathrm{N}$ removal in BRCs. The removal rates of BRCs for $\mathrm{NH}_{4}{ }^{+}-\mathrm{N}$ were not stable. The removal rates of the three groups of devices varied from $55-85 \%$. At the beginning of operation of the device, the removal rate of the BRC-A was as high as $90.38 \%$, that of the BRC-B was $85.17 \%$, and that of the BRC-C was $82.16 \%$, all of which were at high $\mathrm{NH}_{4}{ }^{+}-\mathrm{N}$ removal rates. Electrostatic adsorption is the main mechanism for removing $\mathrm{NH}_{4}{ }^{+} \mathrm{N}$ (Cheng et al., 2019). Dong et al. (2020) studied the effect of ceramsite on organic wastewater treatment and found the removal rate of $\mathrm{NH}_{4}{ }^{+}-\mathrm{N}$ could reach to $85 \%$. Wan et al. (2017) proposed that $\mathrm{P}$ and $\mathrm{Mg}$ on the surface of substrates could react with $\mathrm{NH}_{4}{ }^{+}$, and the $\mathrm{NH}_{4}{ }^{+}-\mathrm{N}$ adsorption capacity could be enhanced by the struvite $\left(\mathrm{MgNH}_{4} \mathrm{PO}_{4} \cdot 6 \mathrm{H}_{2} \mathrm{O}\right)$ formed. It suggested that the high removal rate of $\mathrm{NH}_{4}{ }^{+} \mathrm{N}$ in the earlier stage may be due to the larger specific surface area, strong adsorption effect and $\mathrm{P}, \mathrm{Mg}$ contents of ceramsite. However, with the operation of the device, the removal rate of $\mathrm{NH}_{4}{ }^{+}-\mathrm{N}$ gradually decreased., The removal rates of BRC-A, BRC-B and BRC-C were $62.02 \%, 62.60 \%$ and $61.93 \%$ in $48 \mathrm{~d}$, respectively, which decreased by $28.36 \%, 22.57 \%$ and $20.23 \%$ compared with the initial stage $(0-5 \mathrm{~d})$. The adsorption sites of each layer of materials gradually became saturated with the increase of the operation time of the device, leading to the desorption of $\mathrm{NH}_{4}{ }^{+}-\mathrm{N}$ in the process of rainfall. Since DO concentration above $1.5 \mathrm{mg} / \mathrm{L}$ is essential for nitrification (Hu et al., 2014). $\mathrm{NH}_{4}{ }^{+}-\mathrm{N}$ can be converted to $\mathrm{NO}_{3}{ }^{-}-\mathrm{N}$ by nitrification under aerobic conditions. The anoxic environment caused by the cover of PBs inhibited the growth and reproduction of nitrification bacteria, resulting in the lower $\mathrm{NH}_{4}{ }^{+}-\mathrm{N}$ removal rate of BRC-B and BRC-C than that of BRC-A. At the same time, the water film layer 
formed in the PBs during the infiltration of rainwater also greatly improved the possibility of anaerobic environment. In addition, with the extension of the system operation time, the deposition of suspended particles, the propagation of microorganisms and the development of plant roots led to the decrease of matrix porosity, system blockage and internal environment hypoxia, inhibiting the transformation of $\mathrm{NH}_{4}{ }^{+}-\mathrm{N}$ into $\mathrm{NO}_{3}{ }^{-}-\mathrm{N}$, which was also one of the reasons for the gradual decline of $\mathrm{NH}_{4}{ }^{+}-\mathrm{N}$ removal rate. Also, large amounts of $\mathrm{O}_{2}$ were consumed by the increasing heterotrophic microorganisms and resulted in the inhibition of growth-rate and biological-activity of ammonifying bacteria and nitrifying bacteria as H-PBs released large amount of COD (Zou et al., 2012), Zhang et al. (2019) also found that the removal for $\mathrm{NH}_{4}{ }^{+}-\mathrm{N}$ of wetlands adding no biomass substrate were slightly better than other wetlands with biomass substrate. To a certain extent, this can account for the reason why the $\mathrm{NH}_{4}{ }^{+} \mathrm{N}$ removal rate of BRC-C was always the lowest among three devices. The removal rate of $\mathrm{NH}_{4}{ }^{+}-\mathrm{N}$ decreased greatly after $35 \mathrm{~d}$. In practical engineering, the soil can be loosened at $35 \mathrm{~d}$ to reduce the possibility of anoxic environment and improve the nitrogen removal performance of the system.

Figure 5c. showed the impact of H-PBs on TN removal in BRCs. Under the conditions of artificial simulated rainfall, the influent concentration was $12 \mathrm{mg} / \mathrm{L}$ on average. The effluent concentration of TN of the three groups (BRC-A, BRC-B, BRC-C) were $7.91 \mathrm{mg} / \mathrm{L}, 5.33 \mathrm{mg} / \mathrm{L}$ and $5.00 \mathrm{mg} / \mathrm{L}$ in $48 \mathrm{~d}$ operation of the device, respectively, and the removal rates were $34.08 \%, 55.58 \%$ and $58.33 \%$, respectively. During the operation of the system, the TN removal rate of the three groups of devices increased continuously and gradually tended to be stable. It was worth noting that TN removal rate was improved obviously after adding H-PBs, which is similar to the research of Zhao et al. (2019) The study found that the average TN removal rates of CWs with modified canna leaves, modified rice straw, and modified peanut shells were $59.5 \%, 60.3 \%$, and $61.4 \%$, respectively, which correspondingly increased $17.1-19.0 \%$ compared with the control check. Luo et al. (2018) studied the effect of carbon source on nitrogen transformation process and indicated that CWs with husk rice achieved higher removal rate for TN (73-87\%) than that of control group. The addition of PBs can improve the TN removal rate because the denitrification process is often inhibited by insufficient carbon sources and lack of anoxic environment. On the one hand, PBs can be used as an organic carbon source to promote the denitrification, On the other hand, an anaerobic environment may form inside the PBs, leading to denitrification. The results indicated that the addition of PBs could improve the denitrification rate and change the nitrification and denitrification capacity of the substrate.

\subsubsection{COD removal rate in BRCs}

Figure 5d. showed the impact of H-PBs on COD removal in BRCs. Under the conditions of artificial simulated rainfall, the influent concentration was $30 \mathrm{mg} / \mathrm{L}$ on average, and the effluent COD concentration was kept below $7 \mathrm{mg} / \mathrm{L}$, leading no effluent water quality deterioration. The COD removal rates of BRC-A and BRC-B showed no significant difference and remained at a high level of about $85 \%$. The BRC-C was in a state of low removal rate at the initial stage, but increased rapidly at the later stage, reaching to $87.98 \%$ at $48 \mathrm{~d}$. The reduction of COD in BRCs mainly depends on the decomposition and utilization of microorganisms. Therefore, the main reason accounting for the increase of COD removal 
efficiency of the three groups in the later stage may be that the reproduction of microorganisms enhanced the assimilation of organic matter. However, the low COD removal rate in the BRC-C at the early stage is related to the large amount of carbon released from the PBs at the early stage after the hydrothermal treatment, increasing the COD load of the system. With the operation of the device, the microorganisms in the system were multiplied, the denitrification of the BRC-C was continuously strengthened, with carbon source continuously being needed. So the COD released by the PBs was utilized and degraded, making the COD removal rate of the BRC-C show an increasing trend. The decreased COD was utilized by both denitrifying microbes and other heterotrophic bacteria (Li et al., 2019). Also, the removal rate of COD in BRC-C increased sharply in the initial stage (5-20 d)and then became stable, this result can be explained by rapid consumption of organics by aerobic microbes in the initial phase under conditions of adequate DO, followed by slow degradation in anaerobic phase (Ong et al., 2010).

\section{Conclusions}

The application of agricultural waste biomass in the advanced treatment of low $\mathrm{C} / \mathrm{N}$ rainwater was evaluated in this study. The H-PBs had the highest unit carbon release, which was a suitable choice for carbon source pretreatment method. H-PBs were obtained in an autoclave at $140^{\circ} \mathrm{C}$ for $1 \mathrm{~h}$.

Hydrothermal treatment can destroy the internal structure of lignin, dissolve lignin, and increase the relative content of cellulose and hemicellulose. Meanwhile, after hydrothermal modification, the internal fracture of PBs appeared, the fiber structure became thinner, and the specific surface area significantly increased, providing more space for microbial attachment and growth. Compared with other pretreatment methods, hydrothermal pretreatment was more environmentally friendly. With H-PBs added, TN and $\mathrm{NO}_{3}{ }^{-} \mathrm{N}$ removal efficiency was improved by $24.25 \%$ and $38.22 \%$ compared with the BRC without external carbon source. However, the $\mathrm{NH}_{4}{ }^{+}-\mathrm{N}$ removal rate of the system fluctuated greatly, ranging from $55 \%-85 \%$, and the BRC-C was always at the lowest level among the three groups. In addition, the large carbon release amount of H-PBs in the early stage affected the COD removal rate, but did not deteriorate the effluent quality.

\section{Declarations}

\section{Ethics approval and consent to participate}

Not applicable

\section{Consent for publication}

Not applicable

\section{Availability of data and materials}

Not applicable 


\section{Competing interests}

The authors declare that they have no competing interests

\section{Funding}

The authors acknowledge the financial support of the Natural Science and Technology Support Program of China (grant number: 2015BAL02B04) and Student Practical Innovation Training Program of Nanjing Forestry University (grant number: 2019NFUSPITP0463)

\section{Authors' contributions}

Jing Tuo: conceptualization, methodology, dataacquisition, processing and analysis, write the original paper, review and revise the paper. Shiwei Cao: conceptualization, methodology, dataanalysis, funding acquisition, review and revise the paper, English language service. Muzi Li: methodology, dataacquisition, processing and analysis. Rong Guo: investigation, review and revise the paper. All authors have read and agreed to the published version of the manuscript.

\section{Acknowledgments}

We are especially pleased to thank Zizeng Lin and Wei jie Wang from the Engineering Environment Laboratory for their experimental help.

\section{References}

1. APHA, Awwa WEF (2012) Standard methods for the examination of water and wastewater, 22th ed. Washington, ISBN 978-0875530130

2. Augoustides V, Kasera N, Kolar P (2021) Chemical characterization data of raw Loblolly pine bark nuggets. Chem Data Collect 33:100727. https://doi.org/10.1016/j.cdc.2021.100727

3. Cheng G, Li QH, Su Z, Sheng S, Fu J (2018) Preparation, optimization, and application of sustainable ceramsite substrate from coal fly ash/waterworks sludge/oyster shell for phosphorus immobilization in constructed wetlands. J Cleaner Prod 175:572-581. https://doi.org/10.1016/j.jclepro.2017.12.102

4. Cheng HM, Zhu Q, Xing ZP (2019) Adsorption of ammonia nitrogen in low temperature domestic wastewater by modificaion bentonite. J Cleaner Prod 233:720-730. https://doi.org/10.1016/j.jclepro.2019.06.079

5. Dong JX, Wang YH, Wang LJ, Wang SJ, Li SJ, Ding Y (2020) The performance of porous ceramsites in a biological aerated filter for organic wastewater treatment and simulation analysis. J Water Pro Eng 34:101134. https://doi.org/10.1016/j.jwpe.2020.101134

6. Gold AC, Thompson SP, Piehler MF (2018) Nitrogen cycling processes within stormwater control measures: a review and call for research. Water Res 149:578-587. https://doi.org/10.1016/j.watres.2018.10.036 
7. Hu RT, Zheng XL, Zheng TY, Xin J, Wang H, Sun QG (2019) Effects of carbon availability in a woody carbon source on its nitrate removal behavior in solid-phase denitrifcation. J Environ Manage 246:832-839. https://doi.org/10.1016/j.jenvman.2019.06.057

8. Hu Y, Zhao Y, Rymszewicz A (2014) Robust biological nitrogen removal by creating multiple tides in a single bed tidal flow constucted wetland. Sci Total Environ 470-471:1197-1204. https://doi.org/10.1016/j.scitotenv.2013.10.100

9. Jeong SY, Lee JW (2020) Catalytic effect of iron on sequential Fenton oxidation, hydrothermal treatment, and enzymatic hydrolysis to produce monosaccharide from lignocellulosic biomass. Ind Crops Prod 158:112953. https://doi.org/10.1016/j.indcrop.2020.112953

10. Kavehei E, Shahrabi Farahani B, Jenkins GA, Lemckert C, Adame MF (2021) Soil nitrogen accumulation, denitrification potential, and carbon source tracing in bioretention basins. Water Res 188:116511. https://doi.org/10.1016/j.watres.2020.116511

11. Lee J, Park KY (2020) Impact of hydrotherma pretreatment on anaerobic digestion efficiency for lignocellulosic biomass: influence of pretreatment temperature on the formation of biomassdegrading byproducts. Chemosphere 256:127116. https://doi.org/10.1016/j.chemosphere.2020.127116

12. Liao YH, de Beeck BO, Thielemans K, Ennaert T, Snelders J, Dusselier M, Courtin CM, Sels BF (2020) The role of pretreatment in the catalytic valorization of cellulose. Mol Catal 487:110883. https://doi.org/10.1016/j.mcat.2020.110883

13. Li GB, Wang J, Kong XP (2020) Coprecipitation-based synchronous pesticide encapsulation with chitosan for controlled spinosad release. Carbohydr Polym 249:116865. https://doi.org/10.1016/j.carbpol.2020.116865

14. Li M, Sun LL, Song XF (2019) Carbon sources derived from maize cobs enhanced nitrogen removal in saline constructed wetland microcosms treating mariculture effluents under greenhouse condition. Chemosphere 243:125342. https://doi.org/10.1016/j.chemosphere.2019.125342

15. Li T, Yang XL, Song HL, Wu JJ, Xu JY (2021) Alkali-treated cellulose carrier enhancing denitrification in membrane bioreactor. Int Biodeterior Biodegrad 145:104813. https://doi.org/10.1016/j.ibiod.2019.104813

16. Liu B, Mclean CE, Long DT, Steinman AD, Stevenson RJ (2018) Eutrophication and recovery of a lake inferred from sedimentary diatoms originating from different habitats. Sci Total Environ 628629:1352-1361. https://doi.org/10.1016/j.scitotenv.2018.02.174

17. Luo H, Guan L, Jing Z, Zhang Z, Hu X, Tao M, Wang Y (2020b) Influence of filter layer positions and hydraulic retention time on removal of nitrogen and phosphorus by porous asphalt pavement. Water Sci Technol 81:445-455. https://doi.org/10.2166/wst.2020.110

18. Luo Z, Li S, Zhu X, Ji G (2018) Carbon source effects on nitrogen transformation processes and the quantitative molecular mechanism in long-term flooded constructed wetlands. Ecol Eng 123:19-29. https://doi.org/10.1016/j.ecoleng.2018.08.011 
19. Luo ZX, Li SJ, Zhu XF, Ji GD (2018) Carbon source effects on nitrogen transformation processes and the quantitative molecular mechanism in long-term flooded constructed wetlands. Ecol Eng 123:1929. https://doi.org/10.1016/j.ecoleng.2018.08.011

20. Ong SA, Uchiyama K, Inadama D, Ishida Y, Yamagiwa K (2010) Performance evaluation of laboratory scale up-flow constructed wetlands with different designs and emergent plants. Bioresour Technol 101:7239-7244. https://doi.org/10.1016/j.biortech.2010.04.032

21. Qin J, Cui C, Cui XY, Hussain A, Yang CM (2015) Preparation and characterization of ceramsite from lime mud and coal fly ash. Constr Build Mater 95:10-17. https://doi.org/10.1016/j.conbuildmat.2015.07.106

22. Rashad AM (2019) A short manual on natural pumice as a lightweight aggregate. J Bui Eng 25:100802. https://doi.org/10.1016/j.jobe.2019.100802

23. Ritger PL, Peppas NA (1987) A simple equation for description of solute release âها Fickian and anomalous release from swellable devices. J Controlled Release 5:37-42. https://doi.org/10.1016/0168-3659(87)90035-6

24. Saliling WJB, Westerman PW, Losordo TM (2007) Wood chips and wheat straw as alternative biofilter media for denitrification reactors treating aquaculture and other wastewaters with high nitrate concentrations. Aqu Eng 37:222-233. https://doi.org/10.1016/j.aquaeng.2007.06.003

25. Sarker TR, Pattnaik F, Nanda S, Dalai AK, Meda V, Naik S (2021) Hydrothermal pretreatment technologies for lignocellulosic biomass: A review of steam explosion and subcritical water hydrolysis. Chemosphere 284:131372. https://doi.org/10.1016/j.chemosphere.2021.131372

26. Selig MJ, Viamajala S, Decker SR, Tuker MP, Himmel ME (2007) Deposition of lignin droplets produced during dilute acid pretreatment of maize stems retards enzymatic hydrolysis of cellulose. Biotechnol Prog 23:1333-1339. https://doi.org/10.1021/bp0702018

27. Tan QQ, Li YZ, Li TT, Huang Y, Xing EH, Bi YF, Zhang XW, Chen Q, Li WH (2021) Zeolite beta in situ encapsulation of indole and its derivatives as controlled release formulations for antibacterial. Microporous Mesoporous Mater 325:111342. https://doi.org/10.1016/j.micromeso.2021.111342

28. Tao MN, Jing ZQ, Tao ZK, Luo H, Zuo SM (2021) Improvements of nitrogen removal and electricity generation in microbial fuel cell-constructed wetland with extra corncob for carbon-limited wastewater treatment. J Cleaner Prod 297:126639. https://doi.org/10.1016/j.jclepro.2021.126639

29. Tao ZK, Jing ZQ, Wang Y, Tao MN, Luo H (2021) Higher nitrogen removal achieved in constructed wetland with polyethylene fillers and $\mathrm{NaOH}$-heating pre-treated corn stalks for advanced treatment of low C/N sewage. Environ Sci Pollut Res 28:13829-13841.https://doi.org/ 10.1007/s11356-02011652-9

30. Van Soest PJ, Robertson JB, Lewis BA (1991) Methods for dietary fiber, neutral detergent fiber, and nonstarch polysaccharides in relation to animal nutrition. J Dairy Sci 74:3583-3597. https://doi.org/10.3168/jds.S0022-0302(91)78551-2

31. Wan CL, Ding S, Zhang C, Tan XJ, Zou WG, Liu X, Yang X (2017) Simultaneous recovery of nitrogen and phosphorus from sludge fermentation liquid by zeolite adsorption: mechanism and application. 
Separ Purif Technol 180:1-12. https://doi.org/10.1016/j.seppur.2017.02.031

32. Wang HS, Chen N, Feng CP, Deng Y (2021) Insights into heterotrophic denitrification diversity in wastewater treatment systems: Progress and future prospects based on different carbon sources. Sci Total Environ 780:146521. https://doi.org/10.1016/j.scitotenv.2021.146521

33. Wang J, Chu L (2016) Biological nitrate removal from water and wastewater by solid-phase denitrification process. Biotechnol Adv 34:1103-1112.

https://doi.org/10.1016/j.biotechadv.2016.07.001

34. Xia F, Gong JW, Liu J, Cheng Y, Zhai SR, An QD, Wang HS (2020) Combined liquid hot water with sodium carbonate-oxygen pretreatment to improve enzymatic saccharification of reed. Bioresour Technol 297:122498. https://doi.org/10.1016/j.biortech.2019.122498

35. Yu Q, Liu J, Zhuang XS, Yuan ZH, Wang W, Qi W, Wang Q, Tan XS, Kong XY (2016) Liquid hot water pretreatment of energy grasses and its influence of physico-chemical changes on enzymatic digestibility. Bioresour Technol 199:265-270. https://doi.org/10.1016/j.biortech.2015.07.086

36. Zhang HW, Ahmad Z, Shao YL, Yang ZH, Jia YF, Zhong H (2021) Bioretention for removal of nitrogen: processes, operational conditions, and strategies for improvement. Environ Sci Pollut Res 28:1051910535. https://doi.org/10.1007/s11356-020-12319-1

37. Zhao YF, Song XS, Cao X, Wang YH, Zhao ZM, Si ZH, Yuan SH (2019) Modified solid carbon sources with nitrate adsorption capability combined with nZVI improve the denitrification performance of constructed wetlands. Bioresour Technol 294:122189.

https://doi.org/10.1016/j.biortech.2019.122189

38. Zheng YC, Cao T, Zhang YD, Xiong JQ, Dzakpasu M, Yang D, Yang Q, Liu Y, Li Q, Liu SS, Wang XC (2021) Characterization of dissolved organic matter and carbon release from wetland plants for enhanced nitrogen removal in constructed wetlands for low C-N wastewater treatment. Chemosphere 273:129630. https://doi.org/10.1016/j.chemosphere.2021.129630

39. Zhong F, Huang S, Wu J, Cheng SP, Deng ZF (2019) The use of microalgal biomass as a carbon source for nitrate removal in horizontal subsurface flow constructed wetlands. Ecol Eng 127:263267. https://doi.org/10.1016/j.ecoleng.2018.11.029

40. Zhu ZH, Zhao YC, Guo YY, Zhang RN, Pan Y, Zhou T (2021) A novel additional carbon source derived from rotten fruits:Application for the denitrification from mature landfill leachate and evaluation the economic benefits. Bioresour Technol 334:125244. https://doi.org/10.1016/j.biortech.2021.125244

41. Zou JL, Xu GR, Pan K, Zhou W, Dai Y, Wang X, Zhang D, Hu YC, Ma M (2012) Nitrogen removal and biofilm structure affected by COD/NH4+-N in a biofilter with porous sludge-ceramsite. Sep Purif Technol 94:9-15. https://doi.org/10.1016/j.seppur.2012.03.019

\section{Tables}

Table 2 Quality parameters of simulated rainwater 


\begin{tabular}{|c|c|c|c|c|c|}
\hline $\begin{array}{l}\text { TP } \\
(\mathrm{mg} / \mathrm{L})\end{array}$ & $\begin{array}{l}\mathrm{NH}_{4}{ }^{+}-\mathrm{N} \\
(\mathrm{mg} / \mathrm{L})\end{array}$ & $\begin{array}{l}\mathrm{NO}_{3}^{-}-\mathrm{N} \\
(\mathrm{mg} / \mathrm{L})\end{array}$ & $\begin{array}{l}\mathrm{NO}_{2}^{-}-\mathrm{N} \\
(\mathrm{mg} / \mathrm{L})\end{array}$ & $\mathrm{pH}$ & $\begin{array}{l}\text { COD } \\
(\mathrm{mg} / \mathrm{L})\end{array}$ \\
\hline $1.2 \pm 0.1$ & $5.0 \pm 0.3$ & $3 \pm 0.4$ & $2 \pm 0.4$ & $7.0 \pm 0.5$ & $30 \pm 0.4$ \\
\hline
\end{tabular}

Table3 Comparison of lignocellulose

\begin{tabular}{|llllll|}
\hline $\begin{array}{l}\text { Pretreatment } \\
\text { methods }\end{array}$ & $\begin{array}{l}\text { Cellulose } \\
\square \% \square\end{array}$ & $\begin{array}{l}\text { Hemicellulose } \\
\square \% \square\end{array}$ & $\begin{array}{l}\text { Lignin } \\
\square \% \square\end{array}$ & $\begin{array}{l}\text { Ash } \\
\square \% \square\end{array}$ & $\begin{array}{l}\text { Hot water } \\
\text { soluble matter } \\
\square \% \square\end{array}$ \\
\hline Untreated & 20.70 & 10.25 & 35.65 & 13.86 & 19.54 \\
\hline Hydrothermal-treated & 42.63 & 2.01 & 29.29 & 9.92 & 16.15 \\
\hline
\end{tabular}

Due to technical limitations, Table 1 is only available as a download in the Supplemental Files section.

\section{Figures}

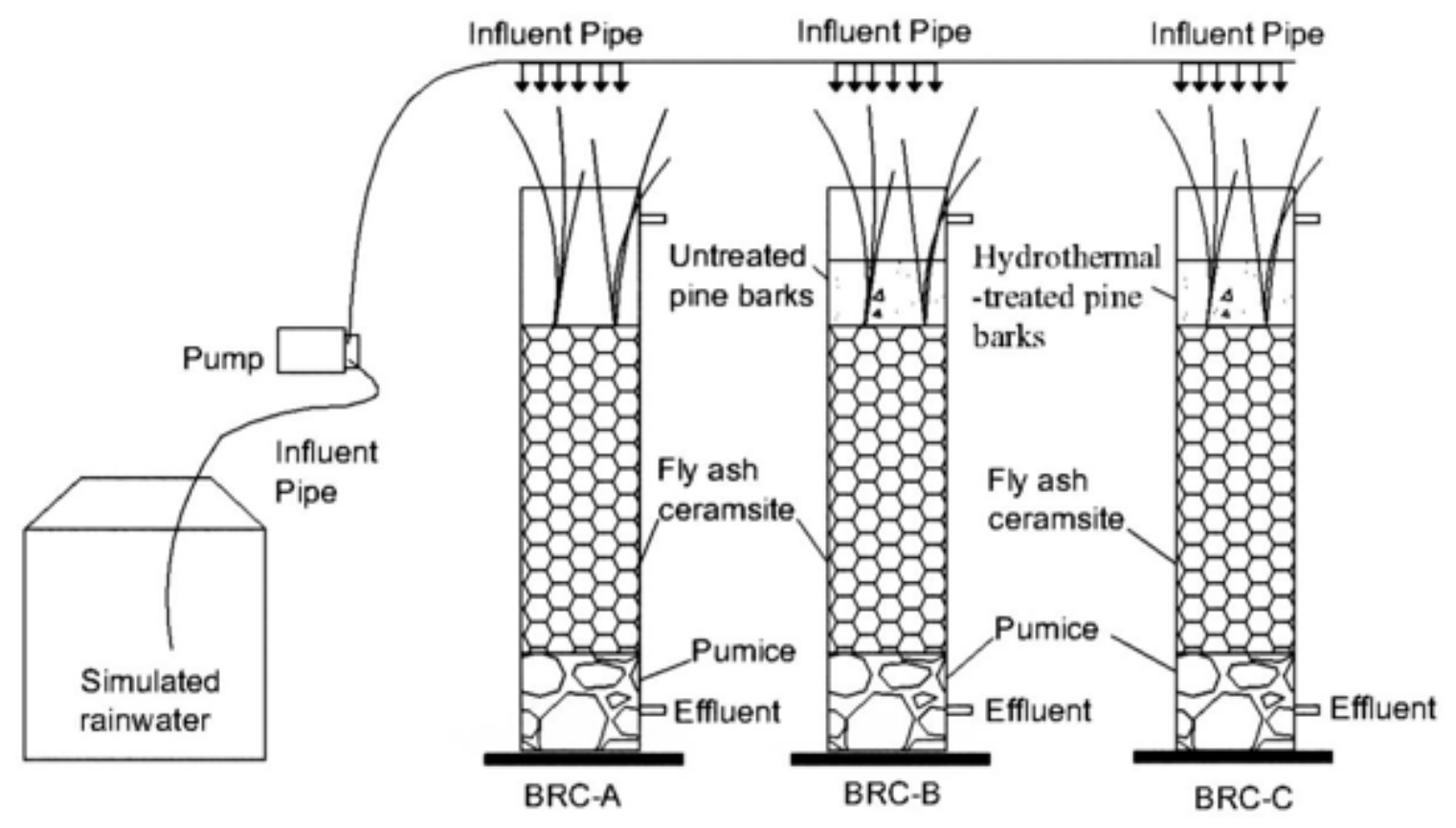

Figure 1

Schematic diagram of experimental bioretention units 

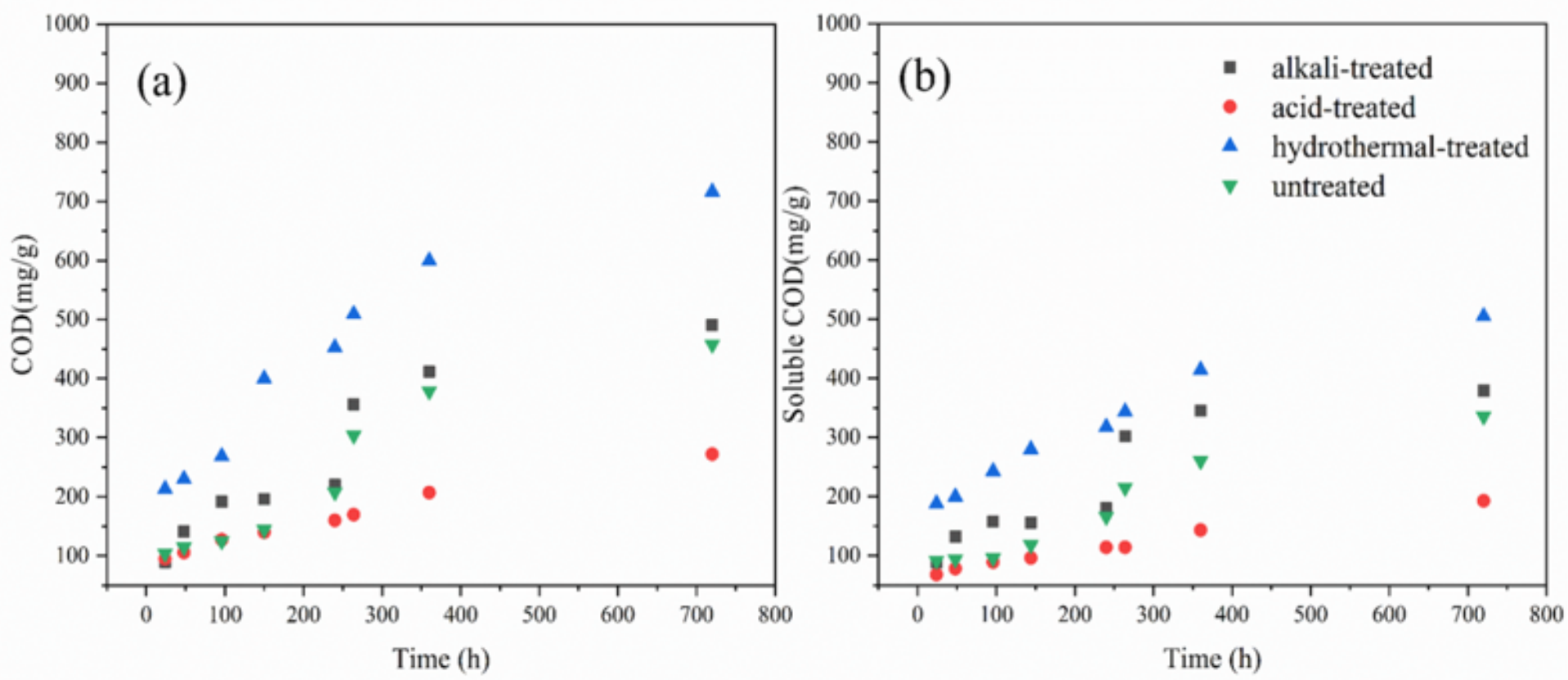

Figure 2

Total and Soluble COD released after pretreatment
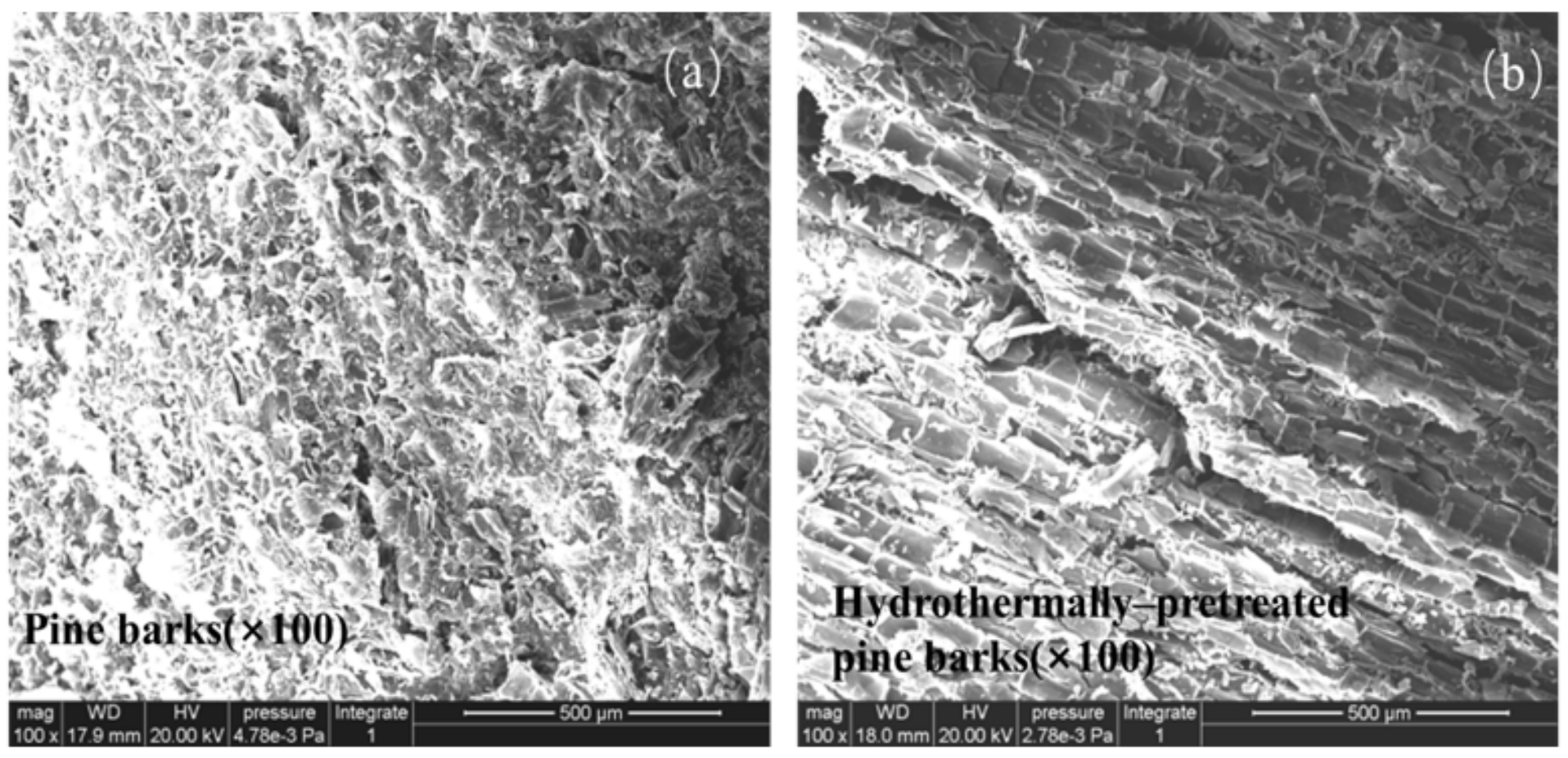

Figure 3

Scanning electron micrograph (SEM) of PBs before $(a, \times 100)$ and after $(b, \times 100)$ hydrothermally pretreatment 


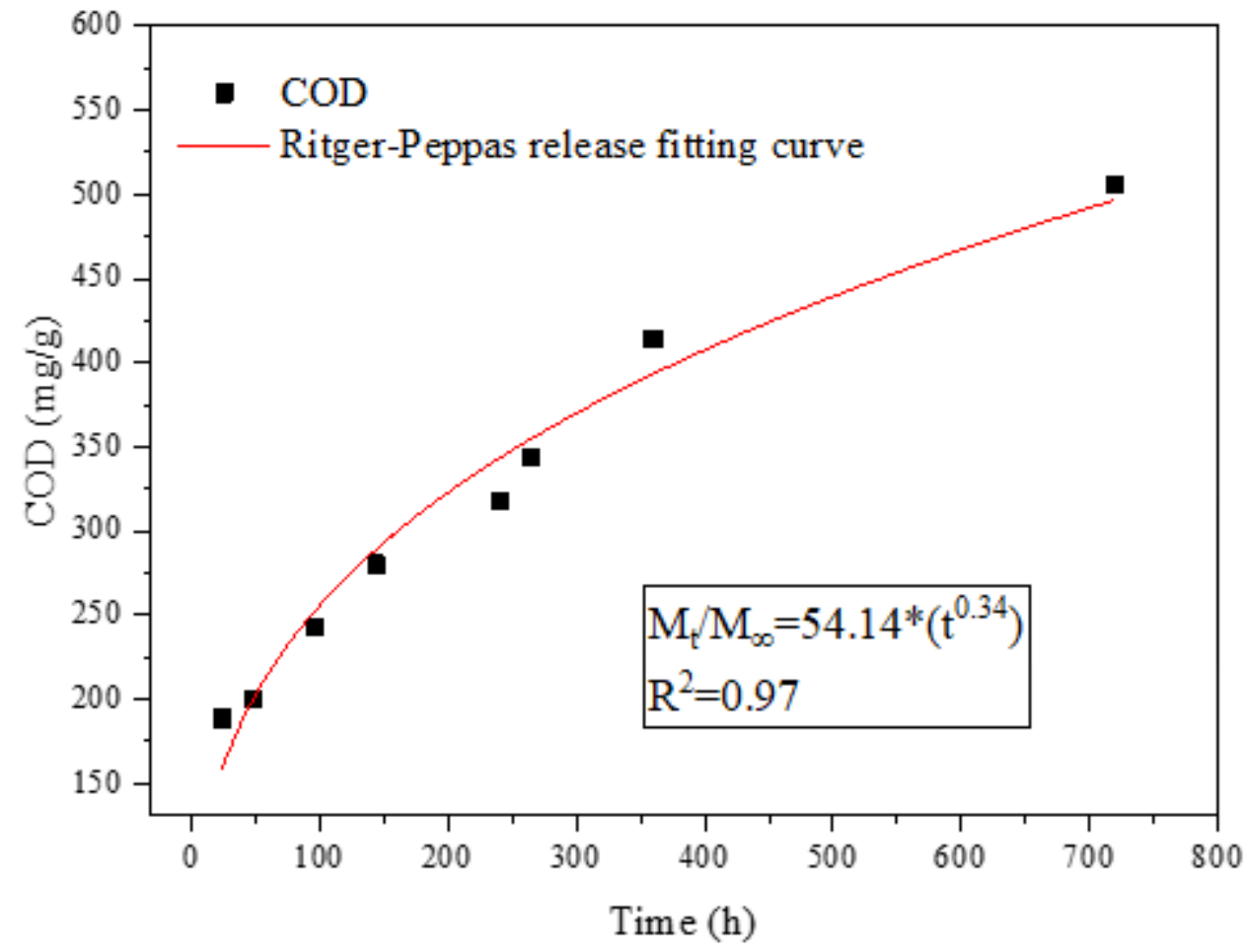

Figure 4

Carbon release kinetics of H-PBs 

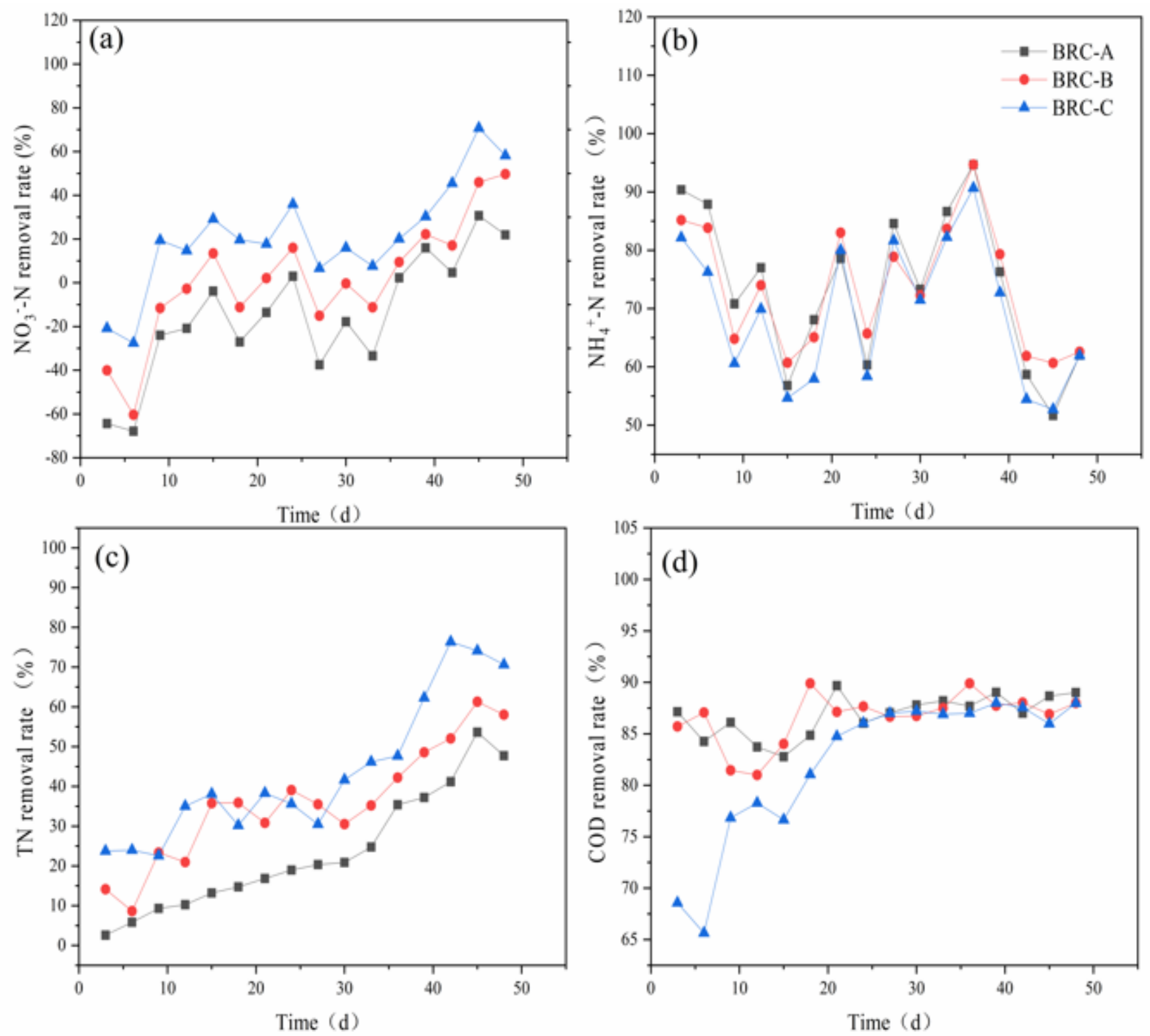

Figure 5

Removal rates of (a) NO3--N, (b) NH4+-N, (c) TN and (d) COD in BRC-A, BRC-B and BRC-C

\section{Supplementary Files}

This is a list of supplementary files associated with this preprint. Click to download.

- Table1.docx 